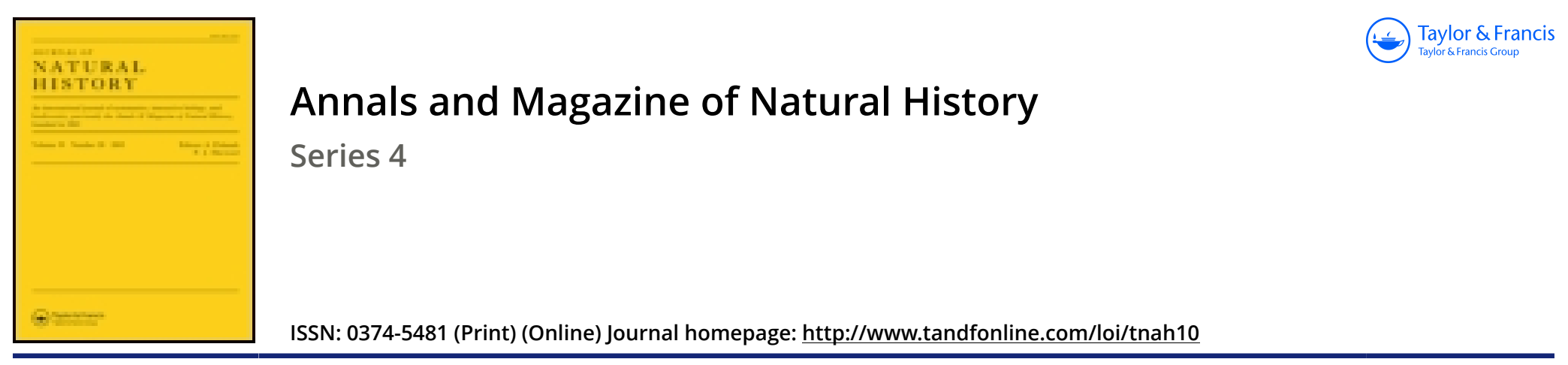

\title{
XVIII.-Conclusion of the history of the wasp and Rhipiphorus paradoxus, with description and figure of the grub of the latter
}

\section{Andrew Murray F.L.S.}

To cite this article: Andrew Murray F.L.S. (1870) XVIII._Conclusion of the history of the wasp and Rhipiphorus paradoxus, with description and figure of the grub of the latter, Annals and Magazine of Natural History, 6:33, 204-213, DOI: 10.1080/00222937008696234

To link to this article: http://dx.doi.org/10.1080/00222937008696234

曲 Published online: 19 Oct 2009.

Submit your article to this journal $\pi$

Џll Article views: 1

Q View related articles $\sqsubset$ 
which I call Macleayius britannicus after the Mare Britannicum of the ancient geographers. I think I have proved that $M$. Van Beneden's theory of geographical distribution of whales is entirely unsupported by facts.

XVIII.-Conclusion of the History of the Wasp and Rhipiphorus paradoxus, with Description and Figure of the Grub of the latter. By ANDrew MurRay, F.L.S.

[Plate XIV.]

When I bade adieu to this subject some months ago, I did so with the promise that, if further investigations by myself or others should show that I was mistaken in the views I had taken up, I should readily and handsomely acknowledge my error.

I have now to redeem my promise; and notwithstanding the natural reluctance which every one feels to acknowledge that they have been mistaken, I make the acknowledgment with pleasure, because it enables me to do an act of justice to one, the accuracy of whose observations I had impugned, and to withdraw any doubt I had expressed as to their reliability. Not that I ever in the remotest degree felt or expressed any doubt as to the genuineness of his observations; but one may be a very truthtul and yet a very inaccurate observer; and this was what I had supposed Mr. Stone to be, and what I am happy now to be able to say was a very unjust supposition. Another alleviation to the wound which my amour propre may be supposed to have received, is the satisfaction of having, as I think, cleared up if not all the unknown and doubtful points in the history of the insect, at least those which last year prevented the question of parasitism being brought to a definite conclusion.

Through the continued kindness of Miss Eleanor Ormerod I have this year been enabled to examine some combs well supplied with Rhipiphori at a less advanced stage than those which I studied last year, as well as to profit by her independent observations. Last year the Rhipiphori were mostly in the state of the perfect insect or chrysalis before $I$ saw them; and I did not then know the larva. The one or two which I did see in the doubly tenanted cells which I described in my first paper on the subject, I mistook for immature pupæ; and when Mr. Smith showed me Mr. Stone's 
Ann. Mag. Nat. Hist.S.4.Vol. 6.PL.XIV.
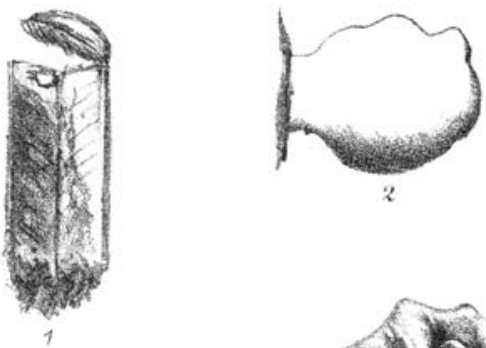

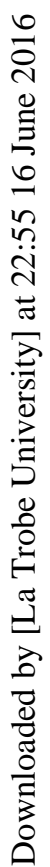
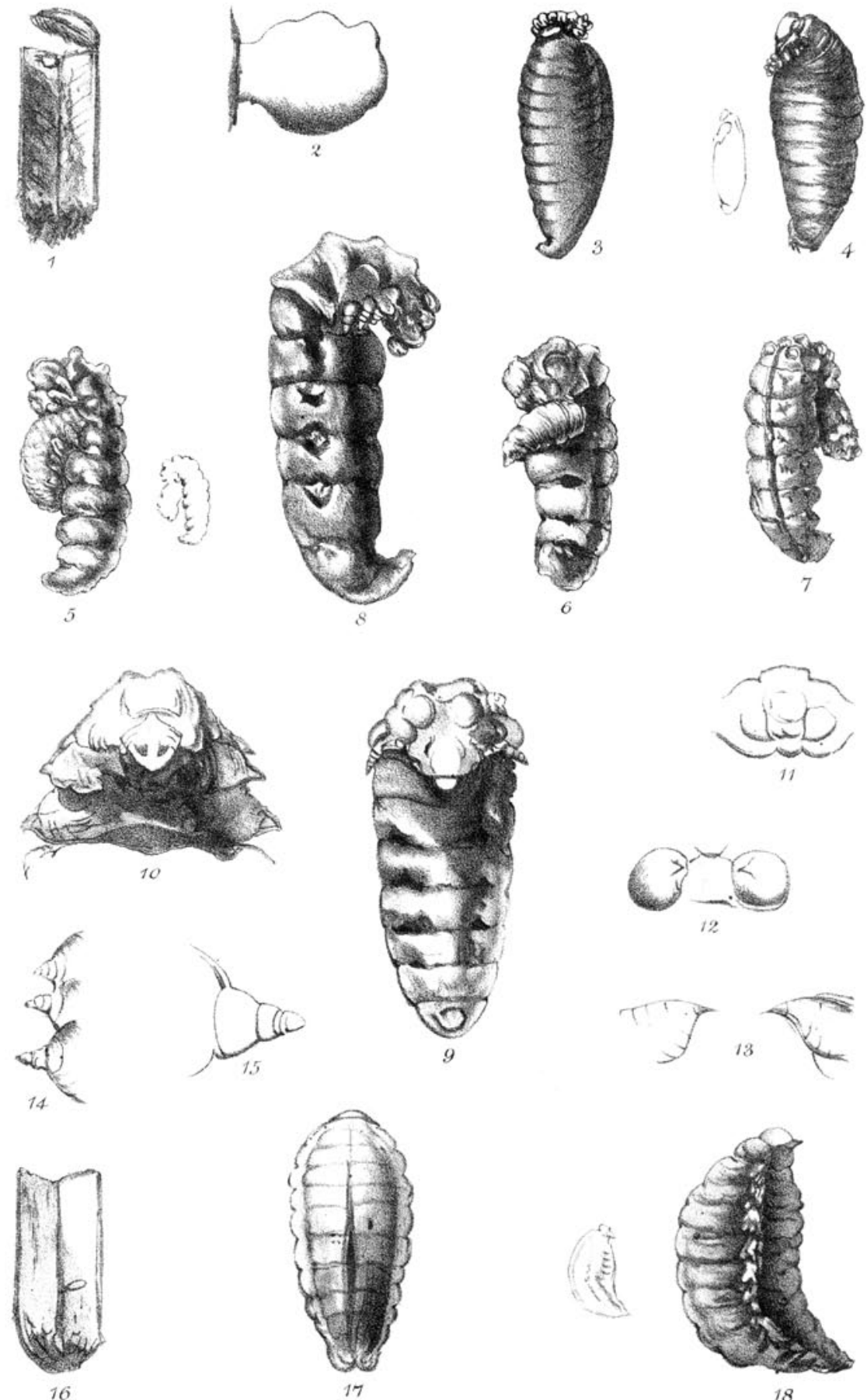

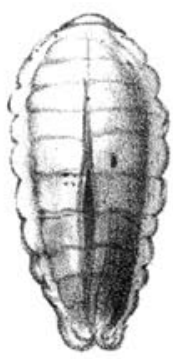

17

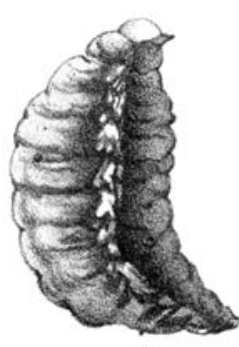

18

Tuffon West lith. 
specimens I did not fully appreciate the difference between them and the wasp-larve, the spirits in which they were preserved having destroyed much of their character. To appreciate the difference between them and the wasp-larvain fact, to make their acquaintance thoroughly, one must see them alive and in all their degrees of development.

Mr. Stone's description, too, which is the only published one we have, does not at all enable one to distinguish them, his most prominent characters being two, which are shared by the wasps themselves-namely, a transparent dark line down the back, and the contents of the body seen through the skin looking like curds. It is true that these characters are more marked in the Rhipiphorus than in the wasp; but as they vary much in degree in the latter, no description, taking them for characters, could ever enable one who has not himself seen them to be sure whether his wasp-grubs were Rhipiphori or not. There are, however, good and sufficiently recognizable characters by which to know them; and to enable the reader to do so I append a full description, with figures, which will supply this lacuna in entomological knowledge.

The opportunities I have had this year have made me thoroughly familiar with them; and the first fact which I have thereby ascertained, or at least become convinced of, is that Rhipiphorus-larvæ are never to be seen in open cells. All our proposed plans for feeding and watching them have therefore fallen to the ground. I have found them abundantly in closed cells, but never once in an open cell ; and the explanation is simply that the Rhipiphorus, as maintained by Mr. Smith, Dr. Chapman, and others, is a parasite, not a guest, and that it only attacks the wasp-grub in cells where it has done feeding and is about to commence to spin up the lid of its cell. This, no doubt, involves the admission that the Rhipiphorus performs the extraordinary feat of growing to its full dimensions upon no more food than an insect no longer than itself. Such a power of assimilation seemed to me incredible; but, like many other facts in natural history which at first seem to us incredible, it turns out not only to be true, but to be capable of natural explanation.

In the first place, I believe that I have seen the Rhipiphori in every stage in the closed cell, from the egg to the perfect insect. As to the egg and earliest stage, I express myself with a certain amount of diffidence, because I have only one observation of it to rely on; and although in an ordinary case that might be sufficient, especially where I have the specimen preserved in spirits to show as a pièce justificative, it is necessary in dealing with these insects to proceed with extra caution, 
because in the allied genera Meloë and Sitoris the larva has been ascertained to go through some extraordinary evolutions in its earlier stages, and at first to appear in a very different form from that which it ultimately assumes.

According to M. Fabre, the only naturalist who has yet observed these changes in Sitaris, its life-history has eleven events :-

1. The egg is laid in the galleries of the Anthophora.

2. A little larva is hatched with six serviceable legs, which remains in its birthplace without food or change of size from October to April.

3. In April it becomes active and attaches itself to the males of Anthophora when they emerge from their cells, which they do before the fernales.

4. From the male it passes to the female Anthophora.

5. From the female it passes to its egg, on which it springs as the female lays it on the surface of the honey on which it was to feed, where it sits as on a raft.

6. It then eats up the egg, which takes it eight days.

7. Seated on the empty shell, floating on the honey, it now undergoes a metamorphosis from its previous slim active carnivorous form to a white fleshy grub, which is no longer carnivorous, but feeds on honey, and is so organized as to float on the surface of the honey, mouth below, spiracles above.

8. After the honey in the cell is done, it changes its skin and passes into something under a corneous envelope like the pupa of a fly.

9. It moults again and once more resembles its second stage (I presume the grub-state; but as it is only said to resemble it, not to revert to it, there may be some difference intended: nothing is said as to its food or feeding in this stage).

10. It then passes into the ordinary pupa-state.

11 th, and lastly. It becomes the perfect insect*.

Without giving absolute faith to all these changes, there is obviously something sufficiently mysterious in the early life of all these creatures to require great care in our observations, and that we should mention every circumstance that strikes us, whether we are certain of its relevancy or not.

Keeping this in view, I speak with extreme caution and, even, doubt of the egg and the earlier stage of the Rhipiphorus. What I observed was this :-

In examining the closed cells of a piece of Rhipiphorized comb, I found the easiest way of opening them and getting a view of their interior was by tearing out the sides instead of

* See account of M. Fabre's writings in 'Natural History Review,' 1862 , p. 129, from which I have taken my information. 
clipping off the lids of the cells. On so opening them I usually pulled out the larva inside; and in many I found the Rhipiphorus-larva in various stages, bigger or smaller than the waspgrub, as the case might be; and the Rhipiphorus is so firmly attached by its mouth to the wasp-grub, that both, as a matter of course, came away together as one body. In one cell, however, it was not so. In it I saw what appeared a very minute Rhipiphorus-larva, in the usual position of these creatures (lying across the throat of the wasp-grub). On pulling out the wasp-grub, the Rhipiphorus-larva did not in this instance come with it; it stretched a little, as if there were two points of adhesion, one to the wall of the cell, the other to the waspgrub; and as I withdrew the latter the adhesion to it gave way, and the Rhipiphorus remained adhering to the cell-wall close below its lip (see Plate XIV. fig. 1). It collapsed back upon it and assumed a somewhat irregular rounded form, and seemed attached to the cell-wall by a broad pedicel (fig. 2). It strikes me that this may have been the Rhipiphorus in an intermediate state between the egg and the larva-still egg at the base, and, as such, adhering to the place on which it was laid, but struggling into life at the head; and possibly the mandibles had already appeared and made some slight incision in the hide of the big wasp-grub, although I could make out neither mandibles nor incision. In the wasp and in many other insects (as the flies for example), probably in all that have flexible skins, the eggshell is not broken in hatching, but becomes the first skin of the larva. The stretching of this object and its adhesion to the grub is the only ground I have for supposing it to be any thing but simply the egg; that adhesion and consequent stretching might have been due merely to the continuity of the two soft bodies touching each other. Now that they (both grub-cell and egg) have been a fortnight in spirits, the egg is merely a little round white dot about the size of a pin's head, still adhering to its place on the cell-wall. At first I thought I could trace something like the lineaments of the larva through the eggshell or skin; but that was, perhaps, imagination.

If $I$ am right in the interpretation of this, the egg is laid, not on the body of the wasp-grub, but on the wall of the cell just within its lip. The usual position of an egg laid by the wasp is shown in fig. 16 .

How long it remains in the egg-form before attacking the wasp-grub, I do not know. The specimen above-mentioned must have been laid at least two days before it reached me. It cannot remain very long, however, before being hatched; for it is a very common characteristic of the closed cells in 
which the Rhipiphori are to be found that the lid of the cell has a hole, or a thin spot, or other defect, in the middle: it is not always observable, nor perhaps even in the majority of instances; but still it is so very often, and I believe the lid in the Rhipiphorized cells is never so strong as in the others. The explanation of it seems to be, that the Rhipiphorus-grub attacks the wasp-grub before it has completed its lid, and does it sufficient injury to prevent its properly finishing it. Where the lid has been finished at all, the egg. has probably been laid just before the grub began to spin up; where it is unfinished, it may have been laid a day or two before.

This imperfection of the lid is of essential advantage to the Rhipiphorus afterwards. I think in one of my former papers I drew attention to the fact that the perfect insect made its way out of the cell in quite a different fashion from the perfect wasp. The wasp cuts its way out through the parchment-like lid with its strong mandibles; but the mandibles of the perfect Rhipiphorus are small, weak, and inadequate to the purpose, and it never uses them; it bursts its way through by main force, pushing the crown of its head against the lid until it gives way. If the lid were of normal strength, the Rhipiphorus might never get out, but die entombed in the chest in which it had incautiously allowed itself to be locked; and the lid would be of normal strength if the egg of the Rhipiphorus were not soon hatched and the wasp-grub attacked before the lid is completed. Possibly the increased heat caused by the closing the cell may start the egg more ravidly than would otherwise have been the case, so that it will be hatched as soon as every thing is ready for it. It is an instance of adaptation of mode of life to subsequent requirements, which looks very analogous to adaptation of structure to purpose.

In the next place I found a number of instances where the Rhipiphorus-egg had apparently only quite recently become a grub. In two instances it was lying across the vertex of the wasp-grub, as shown in fig. 3 ; but more generally it fastens itself obliquely across the breast or shoulder, as a woman carries a child, as in fig. 4, sometimes lying to one side, sometimes to the other, but, so far as I have noticed, the head always over or to the shoulder (baby-fashion), and the tail to the tail (see fig. 4).

The effect of this, I may observe in passing, is to keep the grub with its head towards the mouth of the cell, a position it could not have obtained had it commenced its repast with its head to the tail instead of to the shoulder. This at- 
titude it could not maintain if it ate the grub, that is, tore it in pieces and masticated it; but it does not do that; it sucks it, and never removes its mouth from the spot on which it first fastened. As it sucks it increases in size, and the volume of the wasp-grub diminishes, and the skin contracts and shrivels, keeping the victim always at the mouth of the parasite. So marked is this shrivelling, that latterly, in opening the sides of the cells in search of Rhipiphori, I could, the moment I got a glance at the texture of the body of the wasp-grub, and before I saw the Rhipiphorus, always tell whether it had been attacked by one or not. When not attacked, the wasp-grub has a certain amount of glistening plumpness, although not quite so much as the feeding larva in open cells. After it has been attacked, it becomes duller and opaque or finely shagreened, as it were, and a little more yellowish.

The rate at which the Rhipiphorus consumes the waspgrub, although very rapid, is, according to my observation, not quite so much so as in the instance recorded by $\mathrm{Mr}$. Stone. The nest came into our possession on the 27 th of July. On the 28th I only found one egg (as above-mentioned); all the rest were hatched, most of them very recently, the smallest being about a line in length. On the 31st of July the smallest were nearly 3 lines in length. On the 2nd of August something went wrong with my specimens, and they made no further progress; they began to shrivel and change colour, and I bottled them; but from watching the more advanced specimens when fresh, I saw that after they have become larger than their victim their progress is more rapid than before. That represented in figs. 5, 6, and 7, from which the relative size may be estimated, had completely consumed its victim on the third day thereafter, but not on the second.

I cannot say how far the unnatural condition in which my specimens were may have retarded the progress of the feeding; at first it did not seem to affect them; but, judging from what I saw, I should say that from eight to ten days would be the ordinary time that the Rhipiphorus takes to consume its victim; and adding three or four days for the egg, the whole business would seem to take about a fortnight.

As the Rhipiphorus sucks, the wasp-grub at last, to all appearance, entirely vanishes. It does not do so absolutely, however; for if the chin of the mature Rhipiphorus-grub, now solitary by itself, be lifted up from its breast (on which it constantly rests), there will be found (at least, I have found it in all my experiments) a tiny scrap of yellowish-brown animal matter, Ann.\&Mag. N. Hist. Ser. 4. Vol. vi. 
in which, under the microscope, are to be distinguished a pair of wasp-grub's mandibles. It is the unconsumed part of the skin, and doubtless what Mr. Stone saw, instead of the exuviæ of former tenants adhering to the tail as I had supposed.

I do not think the above facts are explicable on any other view than that I have above stated; and it removes or explains many other difficulties which I last year thought unsurmountable. On looking back at the arguments I then used, they still seem to me, for the most part, sound, all but the premises. These unhappily have the slight defect of being erroneous. I started by assuming that where two eggs were found in a wasp's cell, one of them must belong to the wasp, the other to the Rhipiphorus ; and I reasoned out its life-history as a necessity from that; and were that so, I still think it was a necessary course of life. But I now see that the two eggs have nothing to do with the Rhipiphorus; they are both wasp's (a mere instance of misplaced zeal on the part of the waspmother), of which one is hatched, the other dies. No double tenancy, I venture to say, ever occurs except when a $R h i$ piphorus is present. The instance of a reversed grub to which I drew attention in my first paper, which I then thought might be connected with Rhipiphori, does not now, with our fresh information, seem to belong to it. Its explanation is still to seek; but of the other facts, the only one which seems to require explanation is how the Rhipiphorus-grub can grow as big as a wasp upon no more food than the body of a single wasp-grub. The explanation seems to be this. The wasp-grub has already assimilated all that is necessary to make a body of the bulk of a Rhipiphorus. The materials needed by both are the same. All that is wanted, then, is that the Rhipiphorus should build up its frame of the matter already assimilated by the wasp; in other words, it transfers the assimilated matter into a new shape, and no more. It is an extreme instance of what we know in our own case. We require a vastly greater amount of vegetable matter for food than animal matter, and simply because the latter is, in a great measure, ready assimilated to our hand. It must be the same principle carried to its extreme that enables the Rhipiphorus-grub to do so much upon so little: and in proof of this I may note that it makes almost no excretions; a little, very little, scrap of yellowish-brown jelly, scarcely larger than two pins' heads, resting on the abdomen is all that has dropped from it in the whole course of its life.

The fact that the Rhipiphori which come out of the queens' cells are (like the queen wasps) larger than the other Rhipiphori, but indifferently male and female, is doubtless an- 
other phase of the same phenomenon. They have had more to feed upon; and as apparently they assimilate or remodel almost the whole of the stuff in the wasp-grub, their bulk bears a relative proportion to the amount of food consumed.

\section{Description of Larva of Rhipiphorus paradoxus.}

In its earlier stages it is almost crystalline and transparent; as it grows older it becomes like highly polished cream-coloured marble (especially on the abdomen), except a longitudinal stripe up the back, which remains transparent and allows the eye to penetrate into the interior of the body between the two more solid sides-giving it, when alive, as it were the appearance of a dark stripe. When preserved in spirits, this line of thinner skin sinks and shrinks, so as to make a furrow; but when alive the furrow is only apparent, not real. Looking through this, and generally through the skin, when the insect is alive, a conglomeration of shifting curd-like matter is to be seen, very much as in the wasp, only whiter and more solid.

At first its head is not so much inclined; but in the perfect larva it is bent down upon its breast. Its form has grown into the attitude which its continued position in feeding has prescribed for it. Figs. 8 and 9 show its attitude at these respective periods. When full-grown, the head cannot be forced back or the insect made to lie flat on its face, being tied down, as it were, by the thoracic segments being shorter on the underside than on the upper.

The whole body is soft and concolorous, and when mature is about 5 lines in length. It consists of thirteen segments; but the two anal segments are scarcely distinguishable from each other, and in some cases the three last may be confounded as one.

The head is very small, projecting like a knob from the first. thoracic segment. It isso small that it might be mistaken for a large labrum.

There are no ocelli or eyes, but a faint almost imperceptible narrow subcutaneous streak of brown indicates (as in the waspgrub, but not nearly so distinctly as in it) the inner margin of the future eye. There is a faint longitudinal whitish line running up the middle between them.

The labrum is rounded and tumid at the apex; when seen from below, it is obtuse (see figs. $10 \& 11$ ).

The mandibles are round and stout at the base, rapidly terminating in a very obtuse awl-shape with a very sharp and minute point, which is not central, but more to the front than the middle. 
There are no maxillæ.

There are no antennæ or indication of antennæ.

There are no palpi or indication of palpi.

The labium is not defined.

The thorax is rather developed and bears on each segment on each side of the dorsal line a prominent round crystalline knob with an accessory external addition on the last two segments. The first segment is turned vertically downwards, the second is obliquely placed; the last is horizontal at the top, where the head is in most other insects.

Each segment of the thorax bears two short legs-those on the first segment the smallest, on the last the largest.

The legs consist of three short rapidly tapering segments. They are very short, very obtuse, each segment diminishing as it proceeds from the body, and all starting from the swollen rounded mammiform margins of the thoracic segments. The underside of the thorax is concave.

The segments of the abdomen (with the exception of the last two) are very deeply and distinctly separated; the first segment has dorsal knobs like the preceding thoracic segment, as large but not so crystalline; the second segment has only an indication of them; the rest are without them. Down the back runs the transparent septum already spoken of. The stigmata are very well marked, lying in a pit a little behind the hollow between the segments on each side of the back near the margin. In the hollow itself, just in front of the stigmata, is another, similar pit. On the underside of the abdomen the segments are more or less interrupted in the middle; on each side of it there is a pit in the hollow as on the back. The last two segments are short, scarcely divided, and slightly reverted.

It is unnecessary to describe the pupa, which is merely a colourless undeveloped phantom of the perfect insect, more or less like it the nearer it is to exclusion.

\section{EXPLANATION OF PLATE XIV.}

Fig. 1. Section of closed cell with lid torm off, showing what I suppose to be an ego of Rhipiphorzes near the mouth (slightly magnified).

Fig. 2. The supposed egg in fig. 1, more magnified.

Fig. 3. Wasp-grub taken from a closed cell, with a young Rhipiphorus fastened across its head.

Fig. 4. Wasp-grub taken from a closed cell, with a young Rhipiphorus in its most usual position, lying fastened across its breast like a baby.

Fig. 5. Rhipiphorus with wasp-grub nearly consumed; side view; magnified four times.

Fig. 6. The same; three-quarters front view.

Fig. 7. The same; three-quarters back view. 
Fig. 8. Mature Rhipiphorus-larva after it has finished eating the grub; side view; magnified seven times.

Fig. 9. The same; front view: magnified seven times.

Fig. 10. Head of Rhipiphorus-larva, much magnified.

Fig. 11. The same, looking down on mouth, still more magnified.

Fig. 12. Mouth, showing mandibles looked-at end on.

Fig. 13. Mandible, side view.

Fig. 14. Legs, much magnified.

Fig. 15. The same, still more magnified.

Fig. 16. Cell of wasp, showing ordinary position of wasp's egg.

Fig. 17. Wasp-grub; back view ; magnified four times.

Fig. 18. The same; side view; magnified four times.

\section{XIX.—On some new or little-known Shells \&c. of the Crag} Formations. By Alfred BeLL.

Having in the course of the last few years succeeded in obtaining from the Upper Tertiaries of Great Britain a considerable number of species of shells, Echini, \&c. that have not yet been recorded, the following list of those procured from the different Crags may be useful to others who are interested in the study of these deposits.

Those species marked thus * are new to the Crag fauna (and will be figured shortly from these or other specimens); the others are simply new to the strata to which they are referred.

The terms C. C., R. C., N.C., Chil. ser. are used as contractions of Coralline Crag, Red Crag, Norwich Crag, and the Chillesford series respectively.

Helix hispida, Linné. R. C. Butley.

* Melampus fusiformis, Wood, MS. (n. sp.). Shell cylindrically fusiform, smooth; spire pointed, finely striated lengthwise; whorls 6-7, columellar plaits or folds 2 ; teeth on inner side of outer lip 2. Long. $\frac{1}{2}$ in.

Loc. N. C. Thorpe, Suffolk.

Murex erinaceus, L. R. C. Butley. This, a specimen from Harwich (recorded by Mr. Webster), and another from the N. C., Bramerton, are the only shells of this species mentioned as having been found in the Crag. The former shell (a fragment) is now in the Mus. Pract. Geol., Jermyn St. ; both the others are lost.

Columbella sulcata, Sow. C. C. Sutton.

*Admete Reedii, Bell (n. sp.). Shell ovately fusiform; whorls 6-7, obtusely angulated towards the top, forming a shoulder; spire tapering, suture slight; inner lip reflected; plaits on columella indistinct, finely striated; costæ hardly perceptible. Long. $\frac{6}{10}$ inch.

Loc. C. C. Orford. One specimen in the collection of W. 